Tinjauan Pustaka

\title{
Eosinofilik Esofagitis
}

\author{
Yusri Dianne Jurnalis, Yorva Sayoeti, Widiasteti
}

\begin{abstract}
Abstrak
Eosinofilik esofagitis merupakan gangguan dimana terjadi infiltrasi eosinofil pada mukosa superfisial esophagus yang berhubungan dengan alergi makanan dan kondisi atopi seperti asma, dermatitis atopi, rhinitis alergika dan sering bersamaan dengan Gastroesophageal Reflux Disease (GERD). Diperkirakan insiden tahunan 43 per 10.000 pada anak. Gejala klinis mirip dengan GERD yaitu muntah, regurgitasi, nausea, nyeri dada atau epigastrium, disfagia dan hematemesis. Sekitar $50 \%$ pasien memiliki gejala alergi dan lebih $50 \%$ pasien memiliki orang tua dengan riwayat alergi. Diagnosis dapat ditegakkan berdasarkan pemeriksaan endoskopi dan histologis. Gambaran endoskopi yang ditemukan antara lain feline esophagus, corrugated esophagus, ringed esophagus, atau concentric mucosal rings, eksudat putih, vesikel atau papul dan hilangnya pola vaskular menunjukkan area fokus infiltrasi eosinofil. Diagnosis secara histologis sangat penting dimana kriteria eosinofilik esofagitis adalah jika ditemukan eosinofil $>$ 20/HPF (High Power Field). Terapi yang diberikan adalah terapi diet, farmakologis seperti kortikosteroid sistemik atau topikal, penghambat reseptor leukotrin dan anti IL-5.
\end{abstract}

Kata kunci: eosinofilik esofagitis, alergi makanan, atopi

\begin{abstract}
Eosinophilic esophagitis is a disorder which there is eosinophil infiltration on superficial esophageal mucosa. It's correlated with food allergy and atopy condition such as asthma, atopy dermatitis, rhinitis allergic and often in conjunction with Gastroesophageal Reflux Disease (GERD). The incidence approximately 43/10.000 in children. The symptoms are similar with GERD, which one vomit, regurgitation, nausea, chest or epigastrium pain, dysphagia and hematemesis. About 50\% patient has allergic symptoms and more than 50\% parent of the patient has allergic history. The diagnose can be made base on endoscopic and histological examination. Endoscopic examination shows feline esophagus, corrugated esophagus or concentric mucosal rings, white exudates, vesikel or papul and diminished of vascular pattern, showing eosinophyl infiltration focus area. Histologic diagnosis is very important where the criteria for eosinophilic esophagitis is found eosinophils > 20 / HPF (High Power Field) within the superficial esophageal mucosa. Therapy eosinophilic esophagitis are diet therapy, pharmacological therapy with systemic or topical corticosteroid, leucotriene receptor antagonist and anti IL-5.
\end{abstract}

Keywords:Eosinophilic esophagitis, food allergy, atopy

Affiliasi penulis : Yusri Dianne Jurnalis

Korespondensi : Yusri Dianne Jurnalis Bagian Ilmu Kesehatan Anak Fakultas Kedokteran Universitas Andalas/ RSUP. Dr. M.Djamil

Padang, Email : yusriadiane@yahoo.com

\section{Pendahuluan}

Penyakit eosinofilik saluran cerna merupakan gangguan saluran cerna yang relatif jarang terjadi, berkaitan dengan peningkatan infiltrasi eosinofil tanpa etiologi utama yang mendasari. Penyakit eosinofilik saluran cerna antara lain eosinofilik esofagitis, eosinofilik gastroenteritis, dan eosinofilik colitis. ${ }^{1,2}$ Dalam keadaan normal, esophagus tidak hanya merupakan saluran sederhana untuk menelan makanan dan cairan, tapi organ aktif secara imunologi dapat merespon berbagai rangsangan seperti asam lambung dan alergen yang dapat merangsang eosinofil dan menimbulkan respon inflamasi. ${ }^{3}$

Eosinofilik esofagitis merupakan gangguan dimana terjadi infiltasi eosinofil pada mukosa superfisial esofagus. Infiltrasi eosinofil umumnya terjadi bagian bawah esophagus bersamaan dengan Gastroesophageal Reflux Disease (GERD). Teori terbaru eosinofilik esofagitis dengan infiltrasi eosinofil lebih luas khususnya pada proksimal esofagus memiliki gambaran klinis berbeda dengan GERD. Teori ini semakin diakui sebagai penyebab disfagia, sering dengan riwayat impaksi makanan. ${ }^{3}$ Gambaran klinis, endoskopi dan histologi menjadi lebih jelas walaupun konsensus untuk diagnosis pasti belum ada. Eosinofilik esofagitis dihubungkan dengan alergi makanan dan kondisi atopi seperti asma dan dermatitis atopi. ${ }^{3,4}$

Studi mengenai eosinofilik esofagitis masih sedikit disebabkan masih kurangnya kriteria diagnostik. Informasi mengenai eosinofilik esofagitis lebih banyak pada populasi anak dibanding dewasa, kemungkinan hal ini disebabkan oleh meningkatnya penyelidikan pada anak dengan gangguan gastrointestinal dan para gastroenterologist sering melakukan biopsi. Kasus eosinofilik esofagitis pertama kali digambarkan tahun 1978. Perkiraan insiden tahunan 43 per 100.000 pada anak. ${ }^{3}$ Penelitian epidemiologi oleh Noel dkk, mendapatkan insiden tahunan lebih tinggi yaitu 1 per 10.000 dan $6,8 \%$ anak dengan esofagitis merupakan eosinofilik esofagitis. ${ }^{5}$ Liucouras dkk, mendapatkan $3,4 \%$ anak dengan eosinofilik esofagitis mengalami gejala refluks. ${ }^{6}$ Penulisan refrat ini akan membahas mengenai patogenesis, manifestasi klinis, diagnosis dan tatalaksana eosinofilik esofagitis.

\section{Definisi}

Eosinofilik esofagitis merupakan peradangan pada esofagus yang ditandai infiltrasi eosinofil pada mukosa superfisial esofagus yang berhubungan dengan alergi makanan, infeksi, gastroesophageal reflux dan keadaan atopi seperti asma, rinitis, dermatitis atopi. ${ }^{3}$ 


\section{Epidemiologi}

Eosinofilik esofagitis lebih sering ditemukan pada bangsa Kaukasia dan jenis kelamin laki-laki. Kasus pertama eosinofilik esofagitis telah dijelaskan pada tahun 1978 dengan meningkatnya insiden serta publikasi dalam satu tahun terakhir. Insiden tahunan sekitar 1:10.000 kasus baru pada anak, sering kali salah diagnosis sebagai esofagitis kronik. ${ }^{5}$ Baru-baru ini eosinofilik esofagitis banyak ditemukan di negara Eropa, Australia, Brazil dan Jepang. Penelitian epidemiologi terbaru menunjukkan kejadian meningkat di Amerika Serikat. Prevalensi eosinofilik esofagitis belum diketahui, tetapi beberapa studi menemukan perkiraan prevalensi pada anak 4,3/100.000 dan 2,5/100.000 pada dewasa di Amerika Serikat. Beberapa studi menunjukkan $6-10 \%$ pasien yang didiagnosis GERD ternyata adalah eosinofilik esofagitis. Sebuah studi di Australia menemukan peningkatan eosinofilik esofagitis selama dekade 1995-2004, naik dari 0,05 menjadi 0,89 per 10.000 anak.

Kebanyakan kelainan asimptomatik yang menunjukkan kejadian eosinofilik esofagitis secara signifikan lebih tinggi dari perkiraan awal. Pasien biasanya laki-laki $60-70 \%$ dengan latar belakang alergi seperti peningkatan kadar lgE, eosinofil perifer, penyakit alergi (asma, dermatitis atopi atau rhinitis alergi) dan sensitisasi dengan uji tusukan kulit positif. Pada anak kelainan ini biasanya dengan gejala GERD dan gagal tumbuh, sedangkan pada remaja dengan disfagia dan pada dewasa dengan disfagia, impaksi makanan, striktura dan riwayat penyakit yang tidak diobati. $^{4}$

\section{Etiologi}

Etiologi eosinofilik esofagitis belum sepenuhnya dipahami. Masih tanda tanya apakah eosinofilik esofagitis didasari oleh gangguan alergi, akibat respon imunologi abnormal atau sekunder penyakit refluks berat. Sebelum tahun 1990, eosinofilik esofagitis hanyalah penyakit deskriptif. Kelly dkk (1995), menunjukkan hubungan antara antigen makanan dengan eosinofilik esofagitis, dengan dasar imunologi, sekunder terhadap reaksi hipersensitivitas lambat atau respon hipersensitivitas yang dimediasi sel. Makanan sebagai penyebab eosinofilik esofagitis sering tidak berdasarkan reaksi hipersensitivitas cepat dan beberapa peneliti berpendapat alergi makanan bukanlah penyebab eosinofilik esofagitis. Beberapa artikel telah ditulis mengenai kemungkinan imunologi atau mekanisme alergi yang lain yang mungkin memberikan kontribusi timbulnya eosinofilik esofagitis. Salah satu teori menyatakan bahwa alergen yang terhirup dapat menimbulkan oesinofil esophageal. Kemungkinan terakhir menunjukkan eosinofilik esofagitis bagian dari eosinofilik gastroenteritis. ${ }^{6,7}$

Baru-baru ini, limposit CD8+ telah diidentifikasi sebagai sel $T$ dominan dalam epitel skuamosa pasien eosinofilik esofagitis, sedangkan studi sebelumnya mendapatkan hubungan antara eosinofilik esofagitis dengan atopi. Ini menunjukan hubungan antara atopi dengan eosinofilik esofagitis dan alergi makanan yang berperan dalam patogenesis penyakit ini. Eliminasi makanan tidak dengan segera terjadi perbaikan gejala klinis, perbaikan terjadi dalam 1-2 minggu setelah paparan antigen penyebab dihilangkan. Gejala tidak segera muncul segera setelah terpapar antigen makanan. Biasanya dibutuhkan waktu beberapa hari timbulnya gejala, diduga akibat respon alergi yang dimediasi sel $\mathrm{T}$ dan IgE atau mekanisme lambat sel $\mathrm{T}$ pada patogenesis penyakit ini.

Beberapa peneliti menyatakan kemungkinan aeroalergen berperan pada eosinofilik esofagitis. Mishra dkk, menggunakan model tikus untuk membuktikan bahwa inhalasi Aspergillus menyebabkan eosinofilik esofagitis, dimana allergen meningkatkan kadar eosinofil esophagus dan hiperplasia sel epitel. ${ }^{7}$ Spergel melaporkan kasus pasien eosinofilik esofagitis dengan asma dan rinokonjungtivitis alergi, terjadi eksaserbasi selama musim serbuk sari dan diikuti resolusi selama musim dingin. $^{4}$

\section{Patofisiologi dan patogenesis}

Dalam keadaan

normal traktus gastrointestinal adalah satu-satunya organ nonhemopoetik yang mengandung eosinofil, dimana mayoritas eosinofil berada di lamina propria. Patogenesis eosinofilik gastrointestinal belum jelas, tetapi kondisi atopik respon hipersensitivitas diduga kuat sebagai penyebab. Beberapa penelitian telah membahas kemungkinan patogenesis dari eosinofilik esofagitis. Alergen mengaktivasi sel mast yang bermigrasi ke esofagus melepaskan histamin, eosinofilik cemotactic factor dan platelet activating factor. Selanjutnya eosinofil diaktifkan, melepaskan protein kationik toxic dan peroksidase yang langsung merusak mukosa dan dinding usus. Eosinofil juga mengandung interleukin (IL) seperti IL-3 dan IL-5 yang menimbulkan peradangan jaringan. Pembentukan cincin esofagus berhubungan dengan histamin yang mengaktifkan asetilkolin menyebabkan kontraksi muskularis mukosa esofagus. Cincin ini mungkin sementara dan reversible, meskipun kontraksi terus menerus dari serat otot, hipertropi dan penebalan lapisan otot dari mukosa dapat berkontribusi membentuk scar permanen. Straumann dkk, menyatakan perbedaan eosinofil subpopulasi dengan membandingkan ekspresi protein proinflamasi dan eosinofil jaringan di berbagai bagian traktus gastrointestinal. Eosinofil dan interleukin diukur dalam jaringan esofagus dan usus serta eosinofil darah dari penderita eosinofilik esofagitis dan kontrol. Penderita eosinofilik esofagitis menunjukkan bukti kuat aktivasi eosinofil dengan peningkatan CD-25, IL-5 dan IL-13. ${ }^{7}$

Pada gambar 1 terlihat pengaturan respon inflamasi Th2 pada eosinofilik esofagitis. Antigen dari makanan menginduksi sel Th2 yang melepaskan IL-5 dan IL-13, dimana masing-masingnya mengaktifkan eosinofil dan sel epitel esofagus. IL-13 menginduksi sel epitel untuk menghasilkan eotaxin-3 (suatu chemoattractant eosinofil dan activating factor) dan down-regulate fillagrin. IL-5 dan eotaxin-3 mengaktifkan eosinofil untuk melepaskan Major Basic Protein (MBP) dan Eosinophil-derived Neurotoxin (EDN), yang masing-masingnya mengaktifkan sel mast dan sel dendritik, aktivasi sel mast berperan untuk terjadinya fibrosis. Eosinofil juga memproduksi TGF- $\beta$, mengaktifkan sel-sel epitel dan menyebabkan hiperplasia, fibrosis, dan dismotilitas. Berkurangnya produksi fillagrin dapat menghambat fungsi barier esofagus dan mempertahankan proses ini dengan penyerapan antigen makanan lokal. Variasi genetik yang mempengaruhi ekspresi dari pengaturan molekul-molekul ini dapat berperan adanya risiko eosinofilik esofagitis. ${ }^{8}$ 


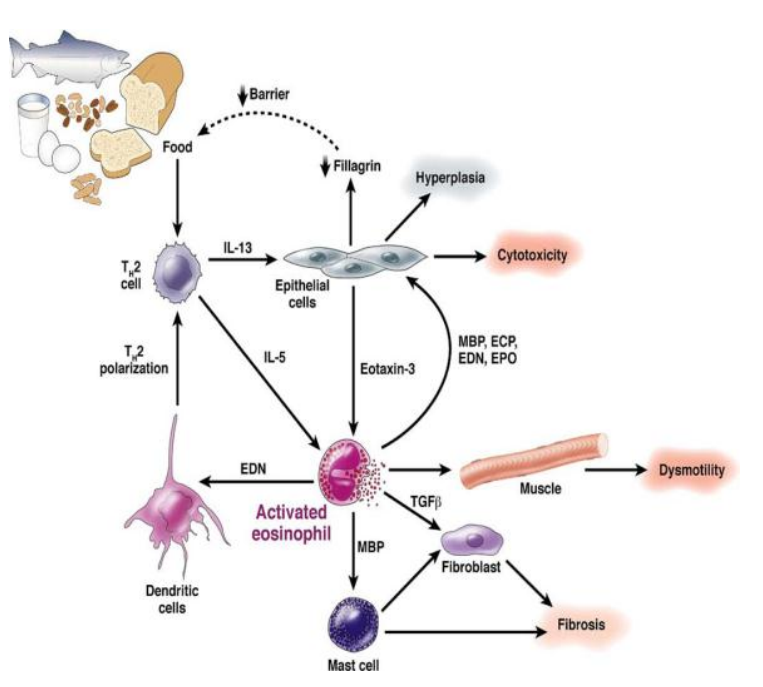

Gambar 1. Patogenesis esofagitis eosinofilik. ${ }^{8}$

Genetik

Ada bukti bahwa esofagitis eosinofilik memiliki hubungan kuat secara familial. ${ }^{6,8}$ Hampir $10 \%$ dari orang tua pasien memiliki riwayat striktura esofagus dan sekitar $8 \%$ biopsi terbukti eosinofilik esofagitis. Dalam sebuah penelitian terhadap 798 pasien anak, 27 orang ditemukan memiliki setidaknya satu saudara kandung atau orang tua dengan eosinofilik esofagitis. EE biasanya diidentifikasi antara saudara kandung atau antara anak dan orang tua. Namun, 3 generasi dari kerabat distal yang terkena telah dilaporkan. ${ }^{8}$

Patel dan Falchuk yang dikutip Rothenberg ${ }^{8}$ melaporkan EE diantara 3 bersaudara dewasa dengan disfagia. Salah satu ukuran digunakan agregasi keluarga adalah risk ratio rekurensi saudara kandung $(\lambda s)$, yang membandingkan rata-rata penyakit antara saudara kandung dengan prevalensi di populasi umum, mengindikasikan peningkatan risiko penyakit diantara saudara kandung dibandingkan dengan populasi umum. Berdasarkan prevalensi populasi untuk EE sekitar 5 per 10.000 orang, sedangkan $\lambda$ s untuk esofagitis eosinofilik adalah sekitar 80.Dibandingkan dengan alergi, seperti atopi atau asma ( $\lambda$ s diperkirakan 2 ), yang jauh lebih tinggi $\lambda$ s untuk $E E$, menunjukkan bahwa gangguan ini mungkin memiliki komponen genetik yang relatif besar. Satu studi terkait single nucleotide polymorphis (SNP) dalam eotaxin-3 dengan EE menggunakan populasi kasus kontrol tetapi penyakit terkait alel hanya hadir pada $14 \%$ dari pasien,

\section{Manifestasi Klinis}

Mayoritas pasien berjenis kelamin laki-laki, biasanya dengan satu atau lebih gejala klinis antara lain muntah, regurgitasi, nausea, nyeri dada atau epigastrium, nafsu makan menurun, dapat juga terjadi gagal tumbuh, hematemesis, dismotilitas esofagus dan disfagia. Gejala dapat lebih sering dan berat pada beberapa pasien sedangkan pada pasien yang lain gejala lebih ringan. Umumnya pasien mengalami disfagia tiap hari atau nausea kronik atau regurgitasi sementara yang lain mungkin memiliki disfagia episode jarang. Sekitar lebih $50 \%$ pasien dengan gejala tambahan alergi seperti asma, eksema atau rhinitis, dan lebih $50 \%$ pasien memiliki orang. tua dengan riwayat alergi (tabel 1).
Tabel 1. Karakteristik eosinofilik esofagitis ${ }^{7}$

\begin{tabular}{l}
\hline Gejala klinis \\
Mirip gejala GERD \\
Muntah, regurgitasi \\
Nyeri dada dan epigastrium \\
Disfagia \\
Gejala berbeda pada anak dan remaja \\
Sering gejala intermitten \\
Laki-laki>perempuan \\
Berhubungan dengan tanda dan gejala (>50\% pasien) \\
Bronkospasme \\
Eksema \\
Rhinitis alergi \\
Riwayat keluarga (35-45\% pasien) \\
Alergi makanan \\
asma
\end{tabular}

Wals dikutip oleh Kamath, ${ }^{7}$ membandingkan antara 21 pasien eosinofilik esofagitis dengan 7 pasien GERD. Sebelas pasien eosinofilik esofagitis memiliki $\mathrm{pH}$ normal sedangkan 7 pasien GERD dengan $\mathrm{pH}$ abnormal. Gejala muntah dan nyeri abdomen terjadi pada kedua kelompok, sedangkan disfagia, diare dan gagal tumbuh dominan pada kelompok eosinofilik esofagitis. Gejala alergi terdapat pada $80 \%$ pasien eosinofilik esofagitis sedangkan $29 \%$ pada kelompok GERD. Riwayat keluarga dengan riwayat alergi $45 \%$ pada kelompok eosinofilik esofagitis (GERD 0\%) dan $50 \%$ kelompok eosinofilik esofagitis ditemukan eosinofil perifer pada $50 \%$ pasien (GERD $0 \%$ ) dengan rata-rata 31 eosinofil per High Powered Field (HPF) dibandingkan 5 eosinofil per HPF pada kelompok GERD. Perbedaan antara eosinofilik esofagitis dengan gastroesophageal reflux disease dapat dilihat pada tabel 2.

Tabel 2. Perbedaan karakteristik eosinofilik esofagitis dengan GERD ${ }^{7}$

\begin{tabular}{ll}
\hline Eosinofilik esofagitis & \\
& Gejala intermitten \\
& pH normal \\
& tidak respon dengan penghambat asam \\
jumlah eosinofil esophagus $>20$ eosinofil per & \\
HPF $\quad$ Gastroesophageal refluks \\
& $\begin{array}{l}\text { Gejala persisten } \\
\text { pH abnormal } \\
\text { respon dengan penghambat asam }\end{array}$ \\
HPF $\quad$ jumlah eosinofil esophagus $1-5$ eosinofil per & \\
\hline
\end{tabular}

\section{Pemeriksaan Penunjang}

\section{Laboratorium}

Gambaran laboratorium belum ada yang dipaparkan secara jelas pada eosinofilik esofagitis oleh karena sensitivitas dan spesifisitas tes laboratorium belum diketahui. Ada variabilitas dalam mendefinisikan level untuk "perifer eosinofilia", dilaporkan eosinofil abnormal berkisar lebih dari 350 eosinofil per $\mathrm{mm}^{3}$ sampai lebih dari 800 eosinofil per $\mathrm{mm}^{3}$. Beberapa laporan tidak menentukan jumlah eosinofil darah yang merupakan diagnosis eosinofilia. Secara keseluruhan, 10\%-50\% dari orang dewasa dan $20 \%-100 \%$ dari anak memiliki peningkatan jumlah eosinofil perifer tetapi biasanya hanya sedikit 
meningkat. Setelah pengobatan dengan flutikason, $88 \%$ dari pasien menunjukkan hitung eosinofil darah menurun. Evaluasi eosinofil darah perifer dapat memberikan bukti yang mendukung untuk eosinofilik esofagitis dan tingkat keterlibatan jaringan tetapi tidak diagnostik, dan korelasi dengan aktivitas penyakit belum diketahui. ${ }^{9}$

\section{Radiolog}

Pemeriksaan radiologis anak dengan eosinofilik esofagitis biasanya normal. Kadang ditemukan penyempitan esofagus adalah paling mungkin sekunder terhadap penebalan dinding esofagus. ${ }^{10}$ Tes diagnostik yang paling umum saat ini untuk mendeteksi eosinofilik esofagitis adalah pemeriksaan barium. Zimmerman dikutip Furuta dkk, ${ }^{9}$ secara retrospektif dari 14 pasien eosinofilik esofagitis mendapatkan 10 pasien dengan striktur esophagus, 10 pasien hiatus hernia dan 9 pasien dengan refluks. ${ }^{9}$

\section{Endoskopi}

Gambaran klasik eosinofilik esofagitis adalah feline esophagus, corrugated esophagus, ringed esophagus, atau concentric mucosal rings. Esofagus kecil dengan diameter internal yang sempit dengan atau tanpa stenosis esophagus proksimal dapat jadi gambaran utama. Eksudat putih, vesikel atau papul dan hilangnya pola vaskular menunjukkan area fokus infiltrasi eosinofil. Esofagus rapuh disebut crepe paper mukosa. Ini menjelaskan air mata esofagus mengikuti dilatasi saat merawat disfagia berhubungan dengan menyempitnya esofagus atau struktur cincin ( seperti striktura). Gambaran endoskopi yang umum adalah cincin mukosa $(81 \%)$, alur-alur $(74 \%)$, penyempitan $(31 \%)$, eksudat (15\%), ukuran kecil $(10 \%)$, dan edema (8\%). ${ }^{9}$ Penelitian Hasosah dkk di Saudi Arabia mendapatkan gambaran endoskopi eosinofilik esofagitis berupa trachealization dan eritema esophagus paling banyak masing-masing $46 \%$, bercak putih $33 \%$, penyempitan $13 \%$ dan normal $13 \%$. ${ }^{11}$

Gambaran endoskopi sangat mambantu tetapi tidak diagnostik tanpa konfirmasi biopsi. Semua pasien dengan gambaran endoskopi sesuai dengan eosinofilik esofagitis harus biopsi proksimal dan distal jaringan esophagus untuk memperkuat diagnosis. Gambaran endoskopi pada eosinofilik esofagitis pada gambar 2 dan 3.

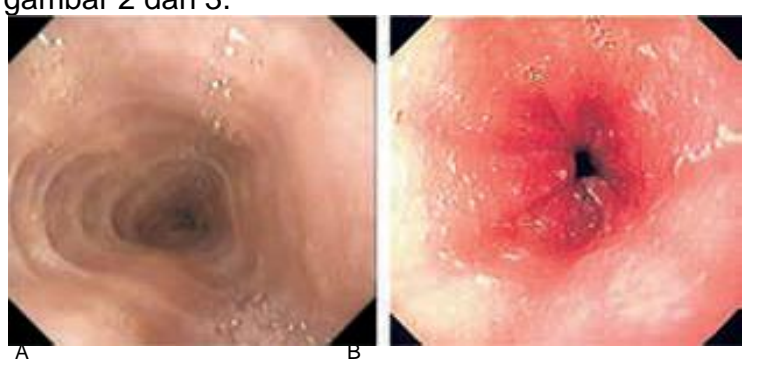

Gambar 2. Gambaran endoskopi eosinofilik esofagitis. $^{9}$

Tampak pada gambar 2A cincin mukosa karena kontraksi sementara atau struktur tetap. Gambaran ini disebut feline esophagus, trachealization atau cincin konsentris. Gambar 2B eksudat keputihan tersebar di seluruh permukaan mukosa. Ini merupakan eosinofilik purulen berkembang melalui epitel esofagus. Eksudat dapat muncul sebagai nodul putih belang-belang atau pola granular dan dapat terjadi sepanjang esofagus.

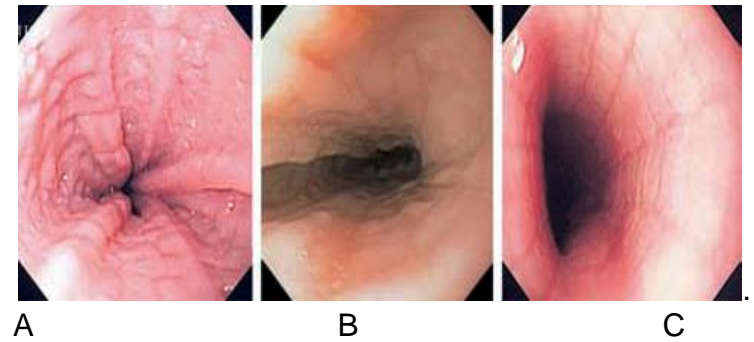

Gambar 3. Gambaran endoskopi eosinofilik esofagitis ${ }^{9}$

Gambar 3A. Esofagus beralur atau berkerut dengan edema dan penebalan mukosa. Alur mencakup permukaan lumen seluruh distal esofagus, sangat tebal dan hampir seperti nodular. Pada gambar 3B tampak dinding esofagus yang berkerut paling menonjol terutama sepanjang dinding kiri lateral dan gambar 3C tampak garis vertikal sepanjang mukosa esofagus. Keadaan ini sering kali muncul ketika esofagus mengembang. ${ }^{9}$

\section{Histopatologi}

Diagnosis eosinofilik esofagitis tergantung pada infiltrasi eosinofil ke epitel squamous. Meskipun tidak ada pernyataan konsensus, tetapi kebanyakan studi untuk menegakkan diagnosis eosinofilik esofagitis bila ditemukan $>20$ eosinofil per HPF tetapi beberapa studi menggunakan $>15$ eosinofil per HPF untuk mendiagnosis eosinofilik esofagitis. ${ }^{9,12}$ Pada GERD infiltrasi eosinofil dapat meningkat di distal esofagus tetapi dengan densitas lebih rendah $<10$ eosinofil/HPF. Oleh karena itu peningkatan eosinofil pada biopsi mid atau proksimal esofagus lebih spesifik untuk eosinofilik esofagitis. Gambaran lain yang dapat membantu tetapi tidak esensial untuk diagnosis antara lain hiperplasia daerah basal, meningkatnya ukuran papil, dengan kumpulan eosinofil pada lapisan superfisial atau mikroabses. ${ }^{9}$ Hasosah dkk, mendapatkan karakteristik histopatologi yaitu degranulasi eosinofil $86 \%$, hiperplasia sel basal $93 \%$, dan mikroabses $73 \%{ }^{11}$

Gambaran histologi eosinofilik esofagitis tampak pada gambar 4. Gambar 4A suatu mikroabses eosinofil dengan lapisan superfisial eosinofil di sepanjang permukaan lumen. Gambar 4B terlihat tampilan dari 2 abses eosinofil besar sepanjang perbatasan lumen esofagus. Ini terjadi di atas dasar epitel hiperplastik dan gambar $4 \mathrm{C}$ dengan daya pandang tinggi tampak mikroabses eosinofil. Inferior dari abses terdapat sejumlah eosinofil, beberapa degranulasi. ${ }^{9}$

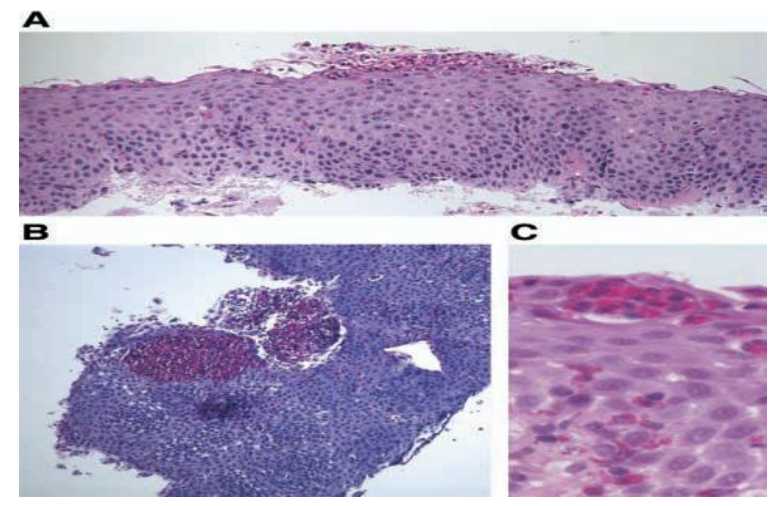

Gambar 4. mikroabses eosinofilik berhubungan dengan eosinofilik esofagitis. ${ }^{9}$ 


\section{Penatalaksanaan \\ Terapi diet}

Beberapa cara terapi diet dan terapi obat tergantung kepada gambaran penyakit. Penghentian makanan penyebab alergi telah terbukti berhasil menghilangkan gejala dan kelainan histologist pada pasien eosinofilik esofagitis. Eliminasi makanan penyebab dapat dilakukan mengikuti beberapa cara. Pertama, dengan mengeliminasi makanan spesifik melalui uji khusus alergen yaitu skin prick dan patch test untuk mengidentifikasi makanan penyebab alergi dan riwayat alergi makanan, selanjutnya menghentikan paparan makanan tersebut. Kedua, penghentian makanan secara empiris yaitu jenis makanan yang paling sering menimbulkan alergi. Ketiga, dengan menggunakan diet elemental yaitu formula asam amino (Neocate) terdiri dari asam amino bebas, sirup jagung dan minyak medium chain triglyceride tanpa diberikan makanan yang lain. 6,9,13,14

Penghentian secara empiris antigenik makanan juga telah dicoba dan berhasil. Studi oleh Kawalwalla,dkk dikutip Furuta dkk $^{9}$, membandingkan efektifitas penghentian 6 makanan yang paling disuka oleh pasien eosinofilik esofagitis dengan menggunakan formula asam amino tanpa diberikan makanan yang lain. Keenam makanan yang paling dianggap antigenik untuk eosinofilik esofagitis adalah susu, kedelai, kacang-kacangan, telur, gandum, ikan/kerang. Eliminasi 6 makanan ini dapat memperbaiki gejala klinis dan kelainan histologi pada $74 \%$ pasien eosinofilik esofagitis pada anak. Pemberian kembali susu adalah penyebab paling umum kambuhnya eosinofilik esofagitis diikuti gandum, telur dan kedelai. Pada anak, susu 18 kali lebih mungkin menjadi pencetus eosinofilik esofagitis. ${ }^{13}$ Diet formula asam amino yang digunakan secara statistik signifikan lebih baik dibanding penghentian 6 makanan secara empiris memperbaiki gejala klinis dan gambaran histologi esophagus. Pada diet formula asam amino terjadi perbaikan secara klinis dan histologis pada $92-98 \%$ pasien, sedangkan pada penghentian 6 jenis makanan terjadi perbaikan $74 \%$ pasien. $^{9,14}$

Penggunaan formula asam amino dimana pasien diperbolehkan hanya minum air saat menelan formula asam amino sampai perbaikan secara klinis dan histologis normal, kemudian setiap jenis makanan secara bertahap kembali diberikan setiap 5-6 hari. Endoskopi dilakukan setelah pemberian 4-5 jenis makanan baru dan 3-4 minggu setelah makanan terakhir diberikan. Perbaikan klinis dan histologi dengan terapi diet ini terjadi pada $>95 \%$ pasien dan tidak ditemukan penurunan berat badan, gangguan elektrolit dan perubahan parameter pertumbuhan yang signifikan pada pasien yang menjalani terapi diet. ${ }^{9,15}$ Ini membutuhkan kerjasama tim yang terdiri dari ahli gastroenterologi, alergi, gizi yang memastikan pasien mendapatkan kalori, cairan dan nutrisi lainnya sesuai kebutuhan dan motivasi yang tinggi dari pasien dan keluarga. $^{14}$

\section{Terapi farmakologis}

Kortikosteroid adalah pengobatan yang efektif untuk eosinofilik esofagitis. Tetapi gejala klinis dan histologis eosinofil kembali berulang setelah obat dihentikan. Terapi kortikosteroid sistemik jangka lama tidak dianggap terapi ideal karena efek samping yang ditimbulkannya. Kortikosteroid oral jangka pendek dapat diberikan pada pasien dengan striktura esofagus atau esofagus sempit, penurunan berat badan atau ketidakmampuan menelan makanan/cairan. Prednison dosis $1-2 \mathrm{mg} / \mathrm{kgbb} / \mathrm{hari}$ maksimum $60 \mathrm{mg} /$ hari dapat diberikan. ${ }^{14}$ Perbaikan secara klinis dan histologis terjadi pada $90 \%$ pasien yang menggunakan kortikosteroid sistemik dan rekuren $95 \%$ jika terapi telah dihentikan. ${ }^{16}$

Flutikason propionate adalah steroid topikal hirup yang sering digunakan untuk terapi asma, juga telah digunakan untuk terapi eosinofilik esofagitis. Flutikason aerosol semprot ditelan bukannya dihirup. Sebelum pemakaian topikal steroid pasien tidak makan dan minum selama 20-30 menit setelah pemakaian obat. Setelah terapi 6-8 minggu dilakukan endoskopi dan pemeriksaan histologis ulang, jika didapatkan perbaikan dosis diturunkan sampai dosis efektif terendah. ${ }^{16}$ Pemakaian dosis tinggi mencapai remisi histologis pada lebih dari $50 \%$ pasien, tapi penyakit kambuh setelah penghentian pada mayoritas pasien. Efek samping antara lain kandidiasis esofagus, epistaksis dan mulut kering. Efek jangka panjang terhadap pertumbuhan tulang, fibrosis belum diketahui. Dosis yang dianjurkan $110 \mu \mathrm{g}$ per semprot (ditelan) untuk anak usia $\leq 10$ tahun dan $220 \mu \mathrm{g}$ per semprot untuk usia $\geq 11$ tahun empat kali sehari diberikan selama 4 minggu. ${ }^{14,17,18}$ Penelitian Schaeefer dkk, mendapatkan prednison oral dan fluticason topikal sama efektif mencapai perbaikan secara klinis maupun histologis dan terjadinya relaps tidak ada perbedaan bermakna secara statistik. ${ }^{18}$

Budesonide yang biasanya untuk terapi pada asma juga telah digunakan untuk eosinofilik esofagitis dengan dosis $1 \mathrm{mg} /$ hari pada anak usia $<10$ tahun dan $2 \mathrm{mg} / \mathrm{hari}$ untuk usia $>10$ tahun. Budesonide yang digunakan berupa budesonide kental yang dibuat dengan mencampurkan $0,5 \mathrm{mg}$ budesonide respul $(0,5$ $\mathrm{mg} / 2 \mathrm{ml}$ ) dengan 5 bungkus sucralose (Splenda). $.14,19$

Terapi tambahan yang telah diteliti adalah antagonis reseptor leukotrine (Montelukast) dan monoklonal antibodi. Walaupun terapi reseptor leukotrine telah menunjukkan perbaikan gejala klinis tetapi tidak secara histologis. Dosis awal $10 \mathrm{mg}$ sekali sehari oral dosis ditingkatkan sampai $100 \mathrm{mg} /$ hari, bila gejala berkurang dosis diturunkan bertahap sampai dosis pemeliharaan $20-40 \mathrm{mg} / \mathrm{hari}$. Dari penelitian gejala kembali muncul setelah penghentian terapi. ${ }^{5,9,13,14}$ Terapi monoklonal antibodi penghambat IL-5 saat ini sedang dievaluasi. Penelitian terbaru pasien yang mendapat anti IL-5 intravena yaitu Mepolizumab (10 mg/kgbb i.v 3 dosis dengan interval 4 minggu) menunjukkan perbaikan gejala dan eosinofilia esofagus secara signifikan dalam 4 minggu setelah dosis pertama. ${ }^{5}$

Terapi supresi asam bukanlah terapi untuk eosinoflik esofagitis, tetapi penting untuk eosinofilik esofagitis. Pasien awalnya diberikan proton pump inhibitor (PPI) untuk memastikan tidak adanya refluks esophageal. Mayoritas Gastroenterologist percaya jumlah eosinofil esofagus tinggi pada eosinofilik esofagitis, penelitian yang dilakukan oleh Ngo dikutip Franciosi $^{14}$ mendapatkan sejumlah eosinofil dapat ditemukan pada pasien GERD. Telah dilaporkan perbaikan gejala klinis setelah diberikan proton pump inhibitor walaupun tidak ada perbaikan histologi jaringan. Dosis PPI yang dianjurkan pada anak 1-2 $\mathrm{mg} / \mathrm{kgbb} / \mathrm{hari}$ dengan dosis maksimum mencapai dosis untuk dewasa. ${ }^{20}$ Respon klinis ini diduga refluks gastroesofageal sekunder atau dismotilitas esophagus dapat terjadi pada pasien eosinofilik esofagitis. Jadi 
semua pasien yang diduga menderita eosinofilik esofagitis diberikan supresi asam untuk mematikan diagnosis eosinofilik esofagitis, bahkan setelah diagnosis ditegakkan terapi tetap dilanjutkan karena refluks sekunder hampir selalu terjadi. ${ }^{14}$

Terapi endoskopi

Dilatasi esofagus merupakan terapi yang bermanfaat untuk eosinofilik esofagitis dengan striktura esofagus. Perawatan harus diberikan saat dilakukan dilatasi karena laserasi mukosa dan perforasi esofagus dapat terjadi. Terapi diet atau terapi steroid dianjurkan sebelum dilakukan dilatasi. ${ }^{6,14}$

\section{Prognosis}

Eosinofilik esofagitis yang di tatalaksana dengan terapi diet dan kortikosteroid tidak ditemukan kematian dan gagal tumbuh. Relaps dapat terjadi 50\% pada satu tahun setelah terapi kortikosteroid oral dan tidak ditemukan peningkatan risiko terjadi malignansi dan eosinofilik gastroenteritis. ${ }^{5}$

\section{Kesimpulan}

Eosinofilik esofagitis merupakan gangguan dimana terjadi infiltasi eosinofil pada mukosa superfisial esophagus diduga berhubungan dengan infeksi, gastroesophageal reflux, alergi makanan dan atopi seperti asma, rhinitis alergika dan dermatitis atopi yang merangsang eosinofil dan menimbulkan respon inflamasi. Gejala eosinofilik esofagitis mirip Gastroesophageal Reflux Disease (GERD) yaitu muntah, regurgitasi, nausea, nyeri dada atau epigastrium, disfagia dan hematemesis. Patogenesis eosinofilik esophagitis melibatkan faktor lingkungan dan genetik, terutama antigen makanan yang menginduksi sel Th2 yang melepaskan IL-5 dan IL-13. Diagnosis dapat ditegakkan berdasarkan pemeriksaan endoskopi dan histologi. Terapi yang diberikan adalah terapi diet, farmakologis seperti kortikosteroid sistemik atau topikal, penghambat reseptor leukotrin dan anti IL-5.

\section{Daftar Pustaka}

1. Shifflet A, Forouhar F, Wu GY. Eosinophilic digestive disease: eosinophilic esophagitis, gastroenteritis and colitis. J Formos Med Assoc 2009;108:834-6.

2. Liacouras CA. Eosinophilic gastrointestinal disorder. Dalam: Parrish CR, penyunting Practical Gastroenterology. Diunduh dari http://www .medicine.virginia. edu / e-health/nutrition-support-team/ nutritionarticles/ Liacouras Article.pdf. tanggal 13 Maret 2011.

3. Yan BM, Shaffer EA. Eosinophilic esophagitis: a newly established cause of dysphagia. World J GAstroenterol 2006;12:2328-33.

4. Spergel JM. Eosinophilic esophagitis in adults and children: evidence for a food allergy component in many patients. Curr Opin Allergy Clin Immunol 2007;7:274-8.

5. Noel RRJ, Rothenberg ME. Eosinophilic esophagitis. Curr opin Pediatr 2005;17:690-94.

6. Liacouras CA. Eosinophilic esophagitis: treatment in 2005. Curr Opin Gastroenterol 2006;22:147-52.

7. Kamath BM, Markowitz JE, Liacouras CA. Allergic bowel disease and eosinophilic gastroenteritis. Dalam: Wyllie R, Hyams JS, penyunting. Pediatric Gastrointestinal and Liver Disease

Pathophysiology/Diagnosis/Management. Edisi ke-3. Philadelphia: Saunders Elsevier 2006:543-8.

8. Rothenberg ME. Biology and treatment of eosinophilic esophagitis. Dalam: Lynch JP, Metz DC, penyunting. Reviews in Basical and Clinical Gastroenterology. Gastroenterology 2009;137:1238-49.

9. Furuta GT, Liacouras CA, Collins MH, Gupta SK, Justinich C, Putnam PE. Eosinophilic esophagitis in children and adults: a systematic review and consensus recommendations for diagnosis and treatment. Gastroenterology 2007;133:1342-63.

10. Anna AS, Rolland S, Fournet JC, Yazbeck S, Droin E. Eosinophilic esophagitis in children: symptons, histology and $\mathrm{pH}$ probe results. J Pediatr Gastroenterol Nutr 2004;39:373-7.

11. Hasosah MY, Sukkar GA, Alsahafi AF, Thabit AO, FAkeeh ME, Al-Zahrani DM. Eosinophilic esophagitis in Saudi children: symptoms, histology and endoscopy. Saudi J Gastroenterol 2011;17:119-23.

12. Odze RD. Pathology of eosinofilik esophagitis: what the clinician needs to know. Am J Gastroenterol 2009;104:485-90.

13. Straumann A, Aceves SS, Blanchard C, Collins $\mathrm{MH}$, Furuta GT, Hirano I, dkk. Pediatric and adult eosinophilic esophagitis: similarities and differences. Allergy 2012;10:1-14.

14. Franciosi JP, Whitehorn TB, Liacouras CA, Pediatric eosinophilic esophagitis: epidemiology, diagnosis and treatment. Current Pediatric Review 2008;4:266-69.

15. Krischner BS. Undetermined colitis and other inflammatory disease. Dalam: Walker WA, Gaulet O, Kleinman R, Sherman PM, Shneider BL, Sanderson IR, penyunting. Pediatric Gastrointestinal Disease, Pathophysiology, Diagnosis, Management. Edisi ke-4.2004:85053.

16. Carr S, Watson W. Eosinophilic esophagitis. AACI 2011;7:1-8.

17. Shannon R. Eosinophilic esophagitis in children, A review and update 2009;32:123-5.

18. Schaefer ET, Fitzgerald JF, Molleston JP, Croffie JM, Pfefferkorn MD, Corkins MR,dkk. Comparison of oral prednisone and topical Fluticasone in the treatment of eosinophilic esophagitis: A randomized trial in children. $J$ Clin Gastroenterology and Hepatology 2008;6:165-73.

19. Dohil R, Newbury R, Fox L, Bastian J, Aceves $S$. Oral viscous budesonide is effective in children with eosinophilic esophagitis in a randomized, placebo-controlled trial. Gastroenterology 2010;139:418-29.

20. Fotis L, Xatzipsalti M, Papadopoulou A. Eosinophilic esophagitis: update on treatment approaches. Hippokratia 2012;16:200-4 